ence of 0.66 per cent would have considerably mag nified the apparent significance of the sex difference.

A series of 7,322 $O$ 's and $A$ 's from Coventry yields women $47 \cdot 609$ per cent, men 51.008 per cent, a difference consistent with that found in the larger samples, but scarcely consistent with zero difference. Wolverhampton, with 6,379 donors, gives a similar result, but certain discrepancies in the case of these figures make it safer not to rely upon them at present.

A large and undoubtedly reliable sample obtained by Dr. Janet Vaughan at Slough, and collnted from time to time at the Galton Laboratory, shows no sex difference in the ratio $A:(A+O)$. Among 70,000 donors, we find women $49 \cdot 604$ per cent and men $49 \cdot 355$ per cent. The women are thus slightly higher in $A$, the difference being non-significant. This result is in definite conflict with those of south-west England and Yorkshire. It is possible, however, that the absence of a sex-difference is to be ascribed to population movements, for it cannot be doubted that the London area, above all others, constantly receives from Scotland, Ireland, Wales and the north an influx of immigrants with a lower percentage of $A$, and a preponderance of men.

As the evidence stands, then, the difference is highly significant in south-western England and moderately significant in Yorkshire, while some supporting evidence is provided in the Midlands by Coventry, and possibly by Wolverhampton. The large sample from Slough is in definite disagreement, though a reasonable explanation can be offered for the discrepancy. Whatever the explanation may be found to be, we feel that the empirical evidence has now accumulated to a point at which its indications must be recognized.

We wish to thank Brigadier L. E. H. Whitby and the staff of the Army Blood Transfusion Service, especially Major B. Lacey, Captain T. Fortescue Fox and Mr. R. J. McCrudden for the excellent facilities so readily placed at our disposal. We are also greatly indebted to Dr. M. S. Stanbury for access to the Yorkshire forms.

Galton Laboratory,

University of London.

Stoke Park Colony,

Stapleton, Bristol. May 6.

\section{Hexose Dehydrogenase}

Experiments on a hexose dehydrogenase have. been in progress in this laboratory since November 1940 , and many useful data have been collected. A recent communication ${ }^{1}$ makes it desirable to publish the results so far obtained.

The most potent preparation of the enzyme has been obtained from Phaseolus mungo and $P$. radiatus seeds. The enzyme has also been found in the small intestines of animals, including the guinea pig. The aerobic and anaerobic dehydrogenation of the hexoses by the enzyme produces ascorbic acid, as found by titration with 2:6 dichlorphenol indophenyl under suitable conditions. The enzyme is equally active towards glucose, galactose and mannose; but fructose and sorbose are not as good substrates as the other three sugars. Fructose and sorbose are, however, converted to ascorbic acid, to a smaller extent, by the enzyme. The disaccharides and the pentoses cannot act as substrates. Thus it would appear that the эnzyme is an aldohexose dehydrogenase. The enzyme preparation frcm the germinating legumes produces both ascorbic acid and dehydroascorbic acid, owing to the simultaneous presence of the oxidizing enzyme (ascorbic acid oxidase), while the enzyme from the small intestines of animals produces ascorbic acid only.

The optimum $p \mathbf{H}$ for the enzyme is $6 \cdot 5$. Potassium cyanide in concentrations of $20 \mathrm{mgm}$. per cent or more, but not hydrogen sulphide, is an inhibitor of the enzyme. Manganese has been found to be the co-enzyme of the dehydrogenase. The addition of the manganese ions in suitable concentrations not only activates the enzyme but also, after electrodialysis of the enzyme extract, synthesis of ascorbic acid takes place only on the addition of manganese. Nickel is very slightly active in this respect, but magnesium, copper and iron are inactive.

The enzyme preparation from the germinating legumes was made by grinding the germinated seeds with cold water, centrifuging and filtering the clear extract through ashless filter paper. From the small intestines, the enzyme extract was made by extracting the acetone-dry intestines with water at $0^{\circ} \mathrm{C}$. for 2-3 hours, centrifuging and filtering. 1 c.c. of the enzyme extract was incubated with 1 c.c. sugar solution (25 mgm.) and 3 c.c. phosphate buffer of $p H 6 \cdot 5,1$ c.c. of distilled water replacing the sugar solution in the control. Time of incubation was 3-4 hours. A few results are given in the accompanying table.

\begin{tabular}{|c|c|c|c|c|}
\hline \multirow{3}{*}{ Source of enzyme } & \multirow{3}{*}{$\begin{array}{c}\% \mathrm{Mn} \\
\text { in incub. } \\
\text { mix. }\end{array}$} & \multicolumn{3}{|c|}{$\begin{array}{l}\text { Ascorbic acid synthesis } \\
\text { (mgm./gm. original sub.) }\end{array}$} \\
\hline & & \multicolumn{2}{|c|}{$\begin{array}{c}\text { Undialysed } \\
\text { enzyme extract }\end{array}$} & \multirow{2}{*}{$\begin{array}{l}\text { Electro- } \\
\text { dialysed } \\
\text { extract }\end{array}$} \\
\hline & & in air & in nitrogen & \\
\hline $\begin{array}{l}\text { P. mungo } \\
\text { "" } \\
\text { P. rädiatus } \\
\text { ", } \\
\text { Rat in'testines }\end{array}$ & $\begin{array}{l}\text { nil } \\
0.001 \\
0.005 \\
\text { nil } \\
0.001 \\
0.001 \\
0.005\end{array}$ & $\begin{array}{l}0.08 \\
0.20 \\
= \\
= \\
=\end{array}$ & $\begin{array}{l}\overline{=} \\
\overline{0} \\
=17 \\
=\end{array}$ & $\begin{array}{l}\frac{\text { nil }}{\overline{0}} \\
0 \cdot 12 \\
\text { trace } \\
\overline{-} \cdot 11 \\
0 \cdot 02\end{array}$ \\
\hline
\end{tabular}

It is evident that on electrodialysis the activity of the enzyme is inhibited slightly, or that some unidentified activating substance is lost. Manganese acts in association with some protein carrier. The protein is probably an albumin. Some evidence for this has been obtained by examining the activity of albumin - manganese mixtures.

The enzyme is partly precipitated by acetone but. attempts to prepare a highly active enzyme in this way have not been successful; the preparation of a stable and highly active dry enzyme is under investigation.

Nov. 15, 1942 [delayed in transmission]. ${ }^{3}$ Baser and Karkum, Proc. 29th Ind. Sci. Congress, Pt. 4, 5 (1942).

IT has been shown [above] that the enzyme preparation from acetone-dry small intestines of animals can synthesize a comparatively small amount of ascorbic acid. The probable explanation is that the enzyme is denatured by acetone treatment. This is suggested by the fact that the enzyme preparation obtained by extracting the fresh jejunum of the goat and guinea pig shows synthesis of a greater amount of ascorbic acid. Four hours incubation of the enzyme extract with glucose at $p \mathbf{H} 6.5$ and in presence of added manganese produces the following results. 